\title{
La sitcom: nueva forma de comicidad, consumo, divertimento e ldentidad en la postmodernidad*
}

\author{
DORIS ADRIANA GALINDO CASTELBLANCO ${ }^{* *}$ \\ maya8116@gmail.com \\ MAYRA ALEJANDRA VALVERDE RENDÓN ${ }^{* * * *}$ \\ maya8116@gmail.com
}

Forma de citar este artículo: Galindo Castelblanco, D. A., \& Valverde Rendón, M. A. (2016). La sitcom: nueva forma de comicidad, consumo, divertimento e Identidad en la postmodernidad. Cuadernos de Lingüística Hispánica, (27), 157-175.

* Artículo de reflexión.

** Licenciada en Lengua Castellana, Inglés y Francés de la Universidad de La Salle, Colombia. Docente de lengua extranjera inglés en la Secretaría de Educación Distrital, Bogotá, Colombia. Aspirante al título de magíster en comunicación y educación en la Universidad Distrital, Bogotá, Colombia.

**** Licenciada en educación básica con énfasis en inglés de la Universidad Distrital "Francisco José de Caldas", Colombia. Docente de lengua extranjera inglés en la Secretaría de Educación Distrital, Bogotá, Colombia. Aspirante al título de magíster en comunicación y educación en la Universidad Distrital, Bogotá, Colombia. 


\title{
Resumen
}

Este artículo tiene como objetivo principal reflexionar sobre la noción de lo cómico en la sociedad postmoderna y su representación en el escenario televisivo: la Sitcom; con el fin de hacer un acercamiento comprensivo a las dinámicas y relaciones existentes entre lo cómico y la identidad cultural, los imaginarios y representaciones colectivas en la sociedad del consumo y del divertimento.

Palabras clave: Sitcom, comicidad, consumo, identidad, multiculturalidad, postmodernidad.

\section{The sitcom: a new form of comedy, consumption, amusement and identity in postmodernity}

\begin{abstract}
The main objective of this paper is to reflect upon the notion of what is comical in postmodern society and its representation in television: the Sitcom. This will allow a comprehensive approach to the existing dynamics and relationships between the idea of the comical and cultural identity, as well as collective imaginaries and representations in a society of consumption and amusement.
\end{abstract}

Key words: Sitcom, comedy, consumption, identity, multiculturalism, postmodernity. 


\section{La sitcom: nouvelle forme de comédie, consommation, divertissement et Identité dans la postmodernité}

\section{Résumé}

Cet article a comme objectif principal, la réflexion sur la notion du comique dans la société postmoderne et sa représentation dans le scénario propre à la télévision: la Sitcom, ayant le but de faire une approche compréhensive aux dynamiques et les rapports existants entre le comique et l'identité culturelle, les imaginaires et représentations collectives dans la société de consommation et du divertissement.

Mots clés: Sitcom, comédie, consommation, identité, multiculturalité, postmodernité.

\section{A sitcom: nova forma de comicidade, consumo, divertimento e Identidade na pós-modernidade}

\section{Resumo}

Este artigo tem como objetivo principal refletir sobre a noção do cômico na sociedade pós-moderna e sua representação no cenário televisivo: a Sitcom; com o fim de fazer uma aproximação compreensiva às dinâmicas e relações existentes entre o cômico e a identidade cultural, os imaginários e representações coletivas na sociedade do consumo e do divertimento.

Palavras chave: Sitcom, comicidade, consumo, identidade, multiculturalidade, pós-modernidade. 
"Paradójicamente con la sociedad bumorística empieza verdaderamente la fase de liquidación de la risa: por primera vez funciona un dispositivo que consigue disolver progresivamente la propensión a reír.”

Lipovetsky

\section{Introducción}

El concepto de lo cómico, y por supuesto de sus elementos constitutivos como la risa y el humor, ha evolucionado y se ha transformado con el paso del tiempo desde la tradición griega a la postmodernidad. Es por ello que cobra vigencia la inquietud de cómo lo cómico se manifiesta, se compone y propone un marco de identidad cultural en nuestra sociedad. Para no ir más allá, el humor de nuestros abuelos es muy diferente al humor de los jóvenes de hoy en día, ni que decir del humor en las comedias griegas con respecto a ese que observamos en el formato televisivo: el de las Sitcom o comedia de situación. Por lo cual, en las siguientes líneas haremos un breve análisis sobre lo cómico en la sociedad postmoderna, desde luego partiendo desde el punto de referencia de lo cómico en sus orígenes con la comedia en la era clásica y retomando algunos conceptos de autores como Bajtín y Bergson quienes, por sus reflexiones, dejaron un gran conocimiento sobre la temática en cuestión. Luego, se profundizará en la Sitcom y las nuevas formas de comicidad e identidad en la narrativa televisiva, para adentrarnos en los nexos existentes entre la sociedad del divertimento televisivo postmoderno y la producción y el consumo de referencias de identidad multicultural en la postmodernidad.

\section{La manifestación de lo cómico en la sociedad postmoderna}

A lo largo de la historia y de las culturas, lo cómico siempre ha estado presente sin importar la época, el género, la edad, el lugar, las condiciones económicas y sociales. Lo cómico ha sido, y es para la sociedad, uno de los aspectos que facilitan la comunicación; a través de él se crítica, se interactúa, se sale de la monotonía, etc., tan importante es que incluso se le han adjudicado poderes curativos, es por ello que, el ser humano ha buscado propiciarlo de diversas maneras, a través de los carnavales, el teatro, los bufones, los chistes, las parodias, las sátiras, las ironías, los disfraces, y la comedia postmoderna: la Sitcom. 
En un primer acercamiento sobre los diversos aspectos que involucra lo cómico, es preciso comenzar a ilustrarnos sobre un término esencial en este recorrido: el humor, visto desde la mirada de dos autores fundamentales: Bajtín y Bergson; para ellos el humor era el medio por el cual la sociedad se liberaba y trataba de cambiar su situación de opresión, lo que implicaba el razonar, el crear. Situación que es muy distinta de lo que ocurre en la actualidad, ya que el humor es utilizado como medio que sirve para relajar. Las reflexiones de Bajtín (1991) acerca de la fiesta carnavalesca en la edad media, dan testimonio de la forma en que el humor permitía acercarse a la comprensión del mundo desde lo ideal, no desde lo real, siendo ese mundo ficcional, idealizado lo que le otorgaba un sentido profundo, ya que en él confluían las ambivalencias, lo bueno, lo malo, lo alto, lo bajo, la muerte, la resurrección, no como aspectos estáticos, sino dotados de movimiento. De modo que, el carnaval, se nutría de utopías, en las que el pueblo se contemplaba a sí mismo como un devenir constante que estaba en transformación, como algo incompleto, que moría, renacía, se renovaba, cambiaba; entonces, a través de lo grotesco, se daba la liberación de los dogmas, el hombre se relativizaba, se daba cuenta de que su existencia no era perfecta, no era eterna, pues tenía un tiempo cíclico de vida y muerte; por lo que se veía abocado a evidenciarlo, a expresarlo a través de la risa. Por su lado, Berson (2003) resaltó que la risa tiene una función social y que la sociedad es el lugar en donde esta adquiere significado, además demostró con ejemplos que la risa tiene la facultad moralizante de corregir lo que se encuentra mal al hacer uso de la ridiculización.

Los aportes de estos dos autores sobre la risa en la edad media y el renacimiento ponen de manifiesto que en nuestro tiempo postmoderno el concepto de humor es distinto, lo cómico ha cambiado hasta llegar a la Sociedad Humorística de Lipovestky (1983), un nuevo ethos toma fuerza, y la risa entra en escena como simulacro; ya no es la fuerza que era capaz de transformar la sociedad, de empoderar a los individuos. Ahora hay vacío en la risa y en el humor; se han convertido en un artilugio que sirve para el ocio, la falsedad y la banalización. La risa se ha disciplinado al ir de la mano con el desarrollo de esas formas modernas de humor, ironía y sarcasmo, como tipos de control tenues e infinitesimales ejercidos sobre las manifestaciones del cuerpo, análogos al adiestramiento disciplinario que analizó Foucault (Lipovetsky, 1983, p. 139). Desde luego, "el código humorístico no es más que una de las formas que adopta ese proceso de destitución de la ilusión y de la autonomización de lo social" (Lipovetsky, 1983, p. 150). Con el advenimiento del capitalismo y las tecnologías emergentes en una sociedad de la vigilancia, y el control institucional en el que la risa es manipulable con fines mercantiles, el humor pasó a ser un artificio de seducción y desposesión del espectador que se encuentra a la espera de algo que lo distraiga de su rutina diaria, un espacio de ocio y de diversión. Así, el humor actual es el de la simpatía, se utiliza para agradar y pasar el tiempo lo mejor posible, de ahí que 
sea el mejor aliado de la publicidad, la moda, el cine y la televisión gracias a que es fútil, inconsistente, pasajero, sin mayores pretensiones, más allá de llamar la atención por un instante para simular que se vive en un mundo feliz sin preocupaciones. Es por ello, que al entrar lo cómico en el escenario de los medios masivos de comunicación como algo de disfrute light ocasionó que el poder de provocación y de identidad transgresora perdiera fuerza debido a que los juegos de palabras, repeticiones, inversiones, etc., dejaron de ser ingeniosos y novedosos para convertirse en fórmulas repetitivas que no sorprenden, que no invitan a pensar y a replantear lo cotidiano desde la risa como fuerza social.

Ahora bien, se comprende que: "El humor pacifica las relaciones entre los seres, desmantela las fuentes de fricciones a la vez que mantiene la exigencia de la originalidad individual. En eso se basa el prestigio social del humor, código de adiestramiento igualitario que debemos concebir aquí como un instrumento de socialización paralelo a los mecanismos disciplinarios" (Lipovetsky, 1983, p. 159) de modo que se está en una cultura del narcisismo, el hedonismo y el psicologismo en la que el individuo piensa que él es el centro de todo y que puede tomar de la sociedad y la cultura los elementos necesarios para sobresalir, por supuesto esto no implica el aislamiento, por el contrario, prevalece la pertenencia al grupo social, solo que para establecer ese contacto se requiere de una actitud desenfadada, vacía, en las que las cosas no tienen importancia, es ahí donde cabe preguntarse: ¿Qué imaginarios tienen los sujetos actuales? ¿Qué les interesa y qué no? ¿Por qué? pues, al parecer, bajo el influjo del humorismo se entra en una democracia narcisista en la que el individuo se psicologiza y desubstancializa al mismo tiempo que mantiene un código comunicacional que le permite estar "satisfecho" consigo mismo y lo que lo rodea. Esta actitud es, ante todo, un pretexto para: "Decirlo todo, pero no tomarse en serio, el humor personalizado es narcisista es tanto una pantalla protectora como un medio cool para salir a escena" (Lipovetsky, 1983, p. 161).

\section{La sitcom: nuevas formas de comicidad e identidad en la narrativa televisiva}

El concepto de comedia y humor ha mutado porque la sociedad lo ha hecho, las instituciones, los significados, las acciones y los valores han cambiado, se han flexibilizado en favor del consumo, predomina el sistema de cambio a través del placer, la felicidad, el hedonismo, la relajación y la información con tan solo acceder a una pantalla, sea la del televisor, el computador, el celular. Por lo tanto, es necesario dar una mirada a la significación de lo cómico en la era antigua para poder contrastarla con aquellas interpretaciones que surgen en la postmodernidad. 
Allí, en la época clásica, la comedia según Pérez (2009), al hablar de los aportes de Vallerdú en su obra "El teatro en la antigüedad", se deriva del griego "Komedia", "El Komos" que se refiere al desfile que se realizaba en honor de Dionisios. Aquí conviene referirnos a esta divinidad a la que estaban dedicadas las festividades. Según, Coulet (1999):

Dioniso nació de la unión de Zeus y Sémele. Loca de celos, Hera, la mujer de Zeus, mandó quemar el cuerpo de Sémele; por suerte, a Zeus le había dado tiempo de coger al niño y ocultarlo en su muslo durante tres meses. Zeus confió entonces su hijo a Ino y Atamante, a quienes Hera todavía celosa, hizo enloquecer. Presa posteriormente de la misma locura, Dioniso vagó por el mundo, revelando por donde pasaba los secretos de la fabricación del vino al llegar a Tracia quiso imponer su culto, lo que dio lugar a un episodio sangriento, representado con frecuencia en la tragedia: el rey del país que se había opuesto a la llegada de este nuevo dios, fue descuartizado por sus propios súbditos. La introducción del culto de Dioniso en Beocia es igualmente sangrienta: Penteo, rey de Tebas, que se oponía al dios, fue despedazado por su propia madre en un arrebato de locura asesina. Poco a poco el culto de Dioniso se fue extendiendo por toda Grecia, siendo vinculado al cultivo de la vid, al vino y a la embriaguez. Dioniso es también el símbolo del poder, de la savia que fluye, de la fuerza vital en general. Todo lo que se relaciona con él está teñido de exuberancia, de violencia e incluso de locura. (p. 15).

En sus inicios, Coulet (1999) destaca que la comedia se desarrolló en la Dóride, cuyo máximo representante fue Epicarmo hacia finales del S. VI y, de quien se heredaría muchas características que pasaron a la comedia ática, entre ellas; chistes verdes, burlas, disfraces. Posteriormente, surge Aristófanes, autor de comedias, destacado en el teatro griego, quien creó obras que invitaban a entretenerse y a pensar de otra manera la realidad que los rodeaba. Por su parte, Badillo (2002) señala que, en su principio, la comedia estaba dedicada a la ejecución de coros fálicos en honor al dios de la fecundidad: Baco. Coros de sentido burlesco, de carácter popular, que constituían un estallido de alegría y un desborde de locura carnavalesca, impregnados de farsa y licencia, de sátira social y política.

Es así como visualizamos que el mundo de la comedia y de lo cómico en la época griega, posee un valor estético inmensurable de expresiones artísticas, morales y políticas que convocaban los intereses y necesidades socio-culturales de un pueblo. Lo cómico se materializaba como elemento de personificación y renovación del ser interior. Por otra parte, y dando un salto a la sociedad postmoderna en donde el escenario se torna cambiante, volátil y ansioso, emerge un nuevo sentir de vida el cual orienta las percepciones e intereses de los individuos. En ese sentir de vida, llegamos al formato de narración televisiva: Sitcom, palabra que proviene del vocablo inglés Situation Comedy 
(comedia de situación); un producto cómico de gran audiencia, diversidad, orientado a todas las teleaudiencias; niños, adolescentes, amas de casa, ejecutivos, etc., por medio de canales como Disney channel, Discovery channel, CNN, MTV, VH1, Space, Fox, ESPN, entre otros. Un tipo distinto de comedia que contrasta fuertemente con aquella de la edad clásica. Una comedia desprovista de un proceso de introspección, cambio y renacer para los individuos. Por el contrario, somos testigos en la postmodernidad de una comedia que sutil y estratégicamente convoca a un sinnúmero de telespectadores a la banalización y ridiculización del individuo. Por lo tanto, ahondaremos en los símbolos y las manifestaciones estéticas orientadas hacia el entendimiento de las nuevas y vertiginosas mutaciones de la identidad y la cultura de un pueblo, de los nuevos imaginarios, así como la irrupción de la postmodernidad, de lo global, en las nuevas concepciones del "yo" en el mundo del consumo y del mercado alrededor de la nueva comicidad.

Ahora bien, la Sitcom es una comedia que presenta los mismos personajes en cada episodio, en situaciones divertidas que son similares a las de la vida cotidiana (López, 2008, p. 17). Bonaut, J. y Grandío, M. (2009, p. 755) nos refieren algunas características de la sitcom: es un producto audiovisual de entretenimiento a capítulo cerrado y de corta duración (22 minutos aprox.); generalmente se rueda en interiores, con un público en directo, y utiliza un decorado de colores vivos único dividido en varios sets; se caracteriza por la inclusión de un disco de risas enlatadas para enfatizar los momentos de humor. De ahí que, al género se le conozca también como comedia enlatada. La sitcom tradicional respeta la estructura clásica aristotélica de tres actos, aunque el guion está muy condicionado por los cortes publicitarios. De esta manera, normalmente se coloca un cliffhanger que es un recurso de guión habitual en el drama para la creación de suspenso y que consiste en mantener una trama central de la serie abierta, inacabada, para fomentar la fidelización entre los espectadores. En la Sitcom es frecuente la utilización de técnicas de la comedia cinematográfica clásica que han sido adaptadas a la televisión como: la sorpresa, el malentendido verbal, el cambio de roles, el engaño o el enredo; las comedias de situación son un género en el que los personajes hablan más que lo que actúan y, por consiguiente, en la mayor parte de las ocasiones, la comicidad recae en los diálogos. Las sitcom han sufrido algunas variaciones de lenguaje, temáticas, tiempo y espacio, y hasta la propia constitución del humor, relacionadas con el devenir de nuevas generaciones y prácticas sociales, además de retomar, para su consecución, características de la radio, el teatro popular y los vodeviles de feria.

La televisión colombiana no ha tenido una larga tradición de producción de comedias de situación como sí ha sido el caso de otros países latinoamericanos como México y Argentina. América Latina se consolida como una de las naciones que compra 
más entretenimiento a los Estados Unidos. Además de películas para cine y programas televisivos, también se adquieren videos con filmes, juegos y otros entretenimientos (García Canclini, 1995). Algunas de las Sitcom transmitidas actualmente son: Modern Family, Jessie, The Big Bang Theory, Two and a Half Man, the New Adventures of Old Christine, Victorious, iCarly, Shake it Up, entre otras.

Es en este panorama que encontramos cómo, a través del consumo televisivo, los individuos entran en contacto con cierta información, se apropian de ella y comienzan a comparar, identificarse, negociar, construir conceptos sobre quiénes son, a dónde pertenecen, si se sienten representados, si es divertido o no, etc., (García Canclini, 1995, p. 13). Estas nuevas relaciones, estos nuevos diálogos están lejos de parecerse a la cultura de la risa grotesca de antaño, en donde se ridiculizaba y se parodiaba para encontrarse con ese ser interior transformado y renovado ante la plenitud del conocimiento en la que lo cómico era el camino hacia la verdad. Hoy asistimos a una "atmósfera cool" en donde existe la individuación y desubstancialización del sujeto, "el humor dominante ya no se acomoda a la inteligencia de las cosas y del lenguaje, a esa superioridad intelectual, es necesario una comicidad discount y pop desprovista de cualquier supereminencia o distancia jerárquica" (Lipovetsky, 1983, p. 141). Además, esto último como síntoma de actitud relajada, despreocupada, cálida, accesible para encontrar esa comunicación desprovista de esencialidad con el entorno y como ruta de acceso directo a la aceptación dentro de la sociedad de lo que constituye mi ser interior. En la comedia de situación, "el humor, a diferencia de la ironía, se presenta como una actitud que expresa cierto tipo de simpatía, de complicidad, aunque sean fingidas, con la persona a quien se dirige; nos reímos con ella, no de ellas" (Lipovetsky, 1983, p. 158). El humor aquí establece relaciones de socialización en tanto que promueve una atmósfera de complicidad; banal y ridícula, pero propicia para jugar el rol del individuo que es capaz de mostrarse sin mayores pretensiones de conocimiento o superioridad. Ya no ridiculizamos a "lo otro" 0 "al otro" porque el humor surge a partir de la degradación del propio "yo" y la Sitcom es una clara muestra de ello.

Es así como trascurre el devenir ante la pantalla chica; desconociendo nuestros arraigos culturales y embebidos por la ensoñación por adquirir un mundo efímero; distante de nuestras verdaderas necesidades. Como consecuencia, la percepción, los sentidos y los saberes se construyen y se de-construyen a diario. La televisión ha arrebatado un sinnúmero de espacios presenciales, de contacto, de discusión y reflexión con el otro y, los ha convertido en espacios de inerme observación de prácticas a seguir debido al enorme poder de persuasión que posee. 
Consecuentemente, este dispositivo tecnológico inmerso en cada hogar, provee continuamente ejemplos de ejercicios socio-culturales de vida, de imaginarios e identidad y, si notamos el auge de la televisión por cable y por suscripción a las cuales acceden cada día más millones de ciudadanos, se puede advertir una incesante muestra de culturas y políticas que se exponen como modelos y entran a confrontar la cultura y política local. Teniendo en cuenta a Martín Barbero (1999):

La televisión es el medio que más radicalmente va a desordenar la idea y los límites del campo de la cultura: sus tajantes separaciones entre realidad y ficción, entre vanguardia y kitsch, entre espacio de ocio y de trabajo...Del espacio, profundizando el desanclaje que produce la modernidad con relación al lugar, desterritorialización de los modos de presencia y relación, de las formas de percibir lo próximo y lo lejano que hacen más cercano lo vivido «a distancia» que lo que cruza nuestro espacio físico cotidianamente (p. 24).

Aquello que se observa a través de la pantalla se materializa en deseos de adquisición de unos imaginarios; de otro barrio, de otro lenguaje, de otra vida, de otra identidad, de otro vestuario, etc. Asistimos a una comunicación televisiva de entretenimiento y de diversión o como lo titula Orozco (2012, p. 41); el "reinado tecnológico-comunicacional de la ludicidad con fuerte condicionamiento mercantil", en donde la narración que expone esta pantalla actúa como somnífero y ensoñación para una audiencia que busca refugiarse en un mundo imaginario casi perfecto en donde abundan los programas "light" que relajan, hacen reír y, por lo cual han ganado su popularidad, talk shows, realities, magazines de chismes, moda y farándula. Es así como, ser parte de la audiencia de una Sitcom, llega a definir por medio del humor círculos de telespectadores con un andamiaje y criterio propios. Es decir, las identidades se hayan enmarcadas dentro de los imaginarios que promueve lo mediático, dependen del tipo de música, canal favorito o Sitcom de moda, en donde nos convertimos en audiencias que consumen para definir nuestra identidad. En resumen, esa identidad se realiza en una espiral de «massmediación globalizante» (Orozco, 2001). Los televidentes no comparten sino que idean, constituyen y practican formas de ser, pensar, actuar y reír, que en la mayoría de ocasiones, resulta una mezcla heterogénea de idiosincrasias, que asumen desconociendo que ya poseían una historia de identificación cultural perdida en el universo del mercado en su presente global. Y como no la reconoce puesto que la sociedad también se haya inscrita en el juego del consumo, la pierde y no le queda más que seguir las modas. En resumen, los medios están creando mediaciones, que no se refiere a aquello "que los medios median", sino que los medios entran en relación: medios y sociedad, medios y vidas cotidianas, medios y movimientos sociales, medios y estructuras de producción” (Martín-Barbero, 2012, p. 30). 


\section{La sociedad del divertimento televisivo postmoderno: el consumo de Imaginarios y representaciones sociales}

La controversia se centra en: ¿Cómo operan los medios de comunicación y cómo están interactuando con lo local y/o global? ¿Qué estructuras sociales y políticas se están trasformando y cómo? En síntesis, todos asisten al único espectáculo de recreación y sostenibilidad de la mercantilización a expensas de las identidades locales y nacionales. "Más allá de la pantalla, los sujetos-audiencia re-producen, re-negocian y re-crean al tiempo que reviven, los referentes televisivos" (Orozco, 2001, p. 45). Y lo que es aún más grave, existe respuesta para la pregunta: ¿hay educación para contrarrestar este dilema?

Es pertinente ahondar en cómo los imaginarios sociales y/o colectivos, junto con las representaciones sociales, se ven influenciados en su construcción, significación y socialización por los programas televisivos, en este caso; la Sitcom, ya que hacemos parte de las masas de audiencias de las sociedades globalizadas, razón por la cual en este apartado reflexionaremos sobre el impacto de la televisión en los imaginarios y las representaciones, ya que hacer parte de la audiencias de un programa implica consumir ideologías, modas, expresiones, a través de un medio masivo que invita a divertirse y relajarse.

Para empezar, es necesario aproximarnos al concepto de imaginario que, de acuerdo con García Canclini en la entrevista realizada por Alicia Lindón (2007), cuando se menciona la palabra imaginario obviamente nos estamos remitiendo a la imaginación, y lo que se imagina es lo que aún no se conoce pero que tiene posibilidad de ser, por ende "los imaginarios corresponden a elaboraciones simbólicas de lo que observamos o de lo que nos atemoriza o desearíamos que existiera" (Lindón, p. 90). Así, los imaginarios son posibilidades latentes que permiten ver más allá de lo conocido para tratar de suplir, complementar u ocupar los vacíos existentes en lo que es tangible, real, conocido. De modo que, los imaginarios van a estar siempre ligados al contexto y al sujeto, pues contamos con referentes que son compartidos y negociados con los demás miembros de la sociedad siendo, por tanto, los imaginarios motores que por su fuerza individual y colectiva pueden mover, cambiar y transformar actitudes. Es decir, que en el momento en que observamos una serie televisiva, por ejemplo, una Sitcom, lo hacemos porque nos sentimos representados; pero también, porque es una forma de ver, tener y entender de forma divertida aunque sea por un instante lo que viven otros, si se es pobre se puede acceder por medio de una pantalla a lo que es la riqueza, estableciéndose un diálogo entre lo que se es y podría ser, lo que se es y no se quiere ser, entre lo que se tiene y lo que no, lo que tiene un lugar y lo que no, localización y deslocalización (Ortiz, 1999, p. 182). 
Por lo cual, no se puede hablar de absolutos pero sí de procesos que se encuentran en un continuo fluir, ya que tanto los imaginarios como las representaciones nos van a ayudar a comprender por qué el concepto de humor se ha ido transformando a medida que las condiciones sociales han cambiado. Así, las representaciones sociales no se pueden definir fácilmente, sin embargo, a pesar de la dificultad en su definición es innegable su relación con el conocimiento, siendo preponderante preguntarse cuál es el lugar del sujeto, ya que es él quien lleva en sí mismo la carga de la expresión social como portador y constructor de significados, de representaciones propias, compartidas y heredadas. Además,

hablar de sujeto en el campo de estudio de las representaciones sociales es hablar del pensamiento, es decir, referirse a procesos que implican dimensiones psíquicas y cognitivas; a la reflexividad mediante el cuestionamiento y el posicionamiento frente a la experiencia; a los conocimientos y al saber; y a la apertura hacia el mundo y los otros. Tales procesos revisten una forma concreta en contenidos representacionales expresados en actos y en palabras, en formas de vivencia, en discursos, en intercambios dialógicos, en afiliaciones y conflictos. (Jodelet, 2008, p. 60).

Imaginarios y representaciones que hayan su lugar en la cultura de lo efímero del consumo, en la fugacidad del espectáculo que ocasiona de acuerdo con García Canclini, una "redefinición del sentido de pertenencia e identidad, organizado cada vez menos por lealtades locales o nacionales y más por la participación en comunidades transnacionales o desterritorializadas de consumidores" (1995, p. 24), lo que se encuentra sustentado en la dinámica de juego entre lo innovador, lo obsoleto y la noción de gusto. La sociedad posmoderna se caracteriza por querer personalizar al individuo, por hacerle sentir que es él quien decide, sin embargo en la "Fase posmoderna de la socialización, el proceso de personalización es un nuevo tipo de control social liberado de los procesos de masificación-reificación-represión" (Lipovetsky, 1983, p. 24). Lo que seduce ya no es un asunto libre, por el contrario es un proceso mercantil, un proceso de consumo que es estudiado meticulosamente por publicistas y psicólogos que convierten a los sujetos en el blanco de la manipulación de las dinámicas capitalistas. En esta forma industriosa de mercado, surge la Sitcom como alimento masificado y globalizado de sentires e identificaciones superfluas. De ahí que, las elecciones de consumo actual, al depender del gusto o liking, de lo que es agradable, o no en un momento dado conforme al estilo de vida y costumbres del televidente, sean pensadas con base en una estética del gusto que apela a lo sensorial, lo emotivo y afectivo para entretener (Grandío, 2009, p. 142). Obviamente, el humor hace parte de las estrategias de seducción, a quién no le gusta reír. La duda está en que se presenta un relajamiento que "invita al descanso, al descompromiso emocional" 
(Lipovetsky, 1983, p. 37), y es así como las Sitcoms "se han convertido en verdaderos laboratorios de experimentación expresiva” (Bonaut y Grandío, 2009, p. 2).

En la cotidianidad de una red social a nivel global, se gestan nuevas y cambiantes formas de relacionarse y desarrollarse como ser humano. Imaginarios y representaciones sociales nacen y se proyectan dentro de una sociedad que avanza con el acelerado ritmo de las tecnologías; las cuales propician nuevos ambientes de interacción traspasando las fronteras de lo local, a través de formas visibles e invisibles que ofrecen al individuo diversos espacios y posibilidades de constituirse y proyectarse como sujeto social ${ }^{1}$ dinamizando precisamente ese imaginario y esas representaciones compartidas. La televisión, sin lugar a dudas, juega un papel muy importante en la cotidianidad de estas audiencias; sea para orientar, enseñar y hasta para condicionar, ya que la televisión como medio es a su vez:

Un lenguaje, es una tecnología, es una institución, es un conjunto de propuestas significantes, es un dispositivo con ciertos potenciales, es el contexto para diversos tipos de interacción y gratificación por parte de las audiencias, es una estética particular y un modo específico de interpelación a las audiencias, es una fuente de mediación cultural, un entorno específico. Cada medio además, va creando o se va asociando a hábitos y ritualidades, a tradiciones, que no fácilmente se abandonan. (Orozco, 2012, p. 47).

Es en ese contexto, donde los espectadores de Sitcoms, expuestos a un sinnúmero de imaginarios y representaciones van otorgándole significado a su contexto socio-cultural con respecto a la información recibida y a lo que puede inferir de ella. Por tanto, estas se constituyen en un recurso estratégico de masificación de símbolos e intereses unilaterales de comportamiento y pensamiento. A través de este producto televisivo se minimiza el poder social de la ciudadanía y se le impone un estilo de vida desprovisto de cualquier reflexión crítica perdiendo su autonomía y capacidad de transformación de prácticas sociales.

\section{Globalización y postmodernidad: identidad y multiculturalidad}

Nos encontramos ante una sociedad en donde uno de los criterios valorativos y, que en la actualidad, posee un valor supremamente sólido para consolidar la ciudadanía, es a través del consumo; todo lo que se adquiere conlleva un valor asociado de identidad; es

1 El hombre ve el mundo como en la caverna de Platón, ejemplo citado por Jamenson (1998, p. 26) "en donde debe dibujar sus imágenes mentales del mundo sobre las paredes que lo confinan. Si queda aquí algún realismo, es el "realismo" surgido de la conmoción producida al captar ese confinamiento y comprender que, por las razones "realismo" surgido de la conmoción producida al captar ese confinamiento y comprender que, por las razones singulares que fueren, parecemos condenados a buscar el pasado histórico a través de nuestras propias imágenes y estereotipos populares del pasado, que en sí mismo queda para siempre fuera de nuestro alcance", puesto que las dinámicas de interacción y reconocimiento del propio yo se han tornado complejas, difusas y cambiantes. Ya no se trata de un sello personal y propio, ahora importa la moda, las decisiones de las masas. 
un referente social, empieza a constituir el marco a través del cual el individuo se proyecta ante su entorno. Ya lo dice García Canclini (1995): "Nos vamos alejando de la época en que las identidades se definían por esencias ahistóricas: ahora se configuran mas bien en el consumo, dependen de lo que uno posee o es capaz de llegar a apropiarse" (p. 14). Los ritos ancestrales, las manualidades, el trabajo laborioso, el trueque, las artesanías, entre otros, se han reemplazado por dispositivos electrónicos, puestos de oficina, cócteles, tratados de libre comercio y arte sintético; aquí, en esta nueva era de la contemporaneidad globalizada. La concepción de identidad se concibe en términos de economía y farándula; cuanto tengo es cuanto expongo, como herramienta social de distinción, poder y participación ciudadana. Y es allí, a través de esa pantalla televisiva, en donde el imaginario y las representaciones colectivas se amalgaman con la práctica de consumo. Adiós a las mentalidades que con sus reflexiones y pensamientos críticos altruistas que contribuían al desarrollo estético del individuo, y demos una bienvenida a los bienes materiales y a la despreocupación frente a la pantalla; parece ser la consigna que cobra vigor. Pero, una vez las necesidades se hayan resueltas, los deseos dejan de existir y se han alcanzado los ideales de ese imaginario, el valor de estos imaginarios asumen una vida fluctuante y transitoria. Es entonces cuando aquellos elementos sociales que nos identifican y nos consolidan como ciudadanos pasan a ser modas temporales sin ningún acervo históricocultural que dé cuenta del valor intrínseco y fundamental que poseen los objetos materiales y morales en la construcción de las naciones.

Y es precisamente esta identidad la que se ha desarrollado heterogéneamente, puesto que lanzado al mundo de la adquisición de bienes y servicios, el individuo, se muestra como un diseño híbrido; adquiriendo saberes y costumbres provenientes de varios escenarios globales posibilitados por el avance científico tecnológico. La televisión, como un solo aspecto de ese avance científico-tecnológico, ha sido una gran ventana a través de la cual se invita al ciudadano a consumir; un consumo mediado. A través de las posibilidades de la televisión por cable y por suscripción accedemos, las 24 horas del día, a un mundo materializado en diversidad de imágenes, lenguajes, estereotipos, culturas. Además, es por medio de este aparato electrónico donde las identidades se perfilan; por edad, por moda, por productos, por gustos, etc. La narrativa televisiva se percibe como máquina de contar historias y un referente primordial de la cultura emocional de un pueblo. Por lo cual, su comunicación se vuelve efectiva si converge con los modos simbólicos de la sociedad, esos que indican los sentimientos, los valores y los pensamientos válidos para el sentido público (Rincón, 2006). Por ello, los individuos, que interpretando los mensajes de la era posmoderna, entran a participar y dinamizar las relaciones sociales emergentes dentro de ese mundo globalizado. 
Nuevas culturas y nuevos territorios al alcance del día y en donde interactuamos como consumidores sin participación ciudadana; en una sola frase: “...las identidades posmodernas son transterritoriales y multilingüísticas" (García Canclini, 1995, p. 30). La Sitcom representa claramente este aspecto en donde visualizamos que las identidades surgen en un ambiente de encuentro de diversidad de culturas en donde el acercamiento a idiosincrasias globales permean el acervo cultural local al ser un producto televisivo masificado de procedencia extranjera. Se trata de percibir que nos encontramos ante una comunicación asidua entre sociedades en donde, de forma simultánea estamos expuestos a diversos productos simbólicos de las sociedades, puesto que "los bienes materiales, mensajes culturales y artísticos viajan en un tren virtual que recorre los cinco continentes, y aun cuando no los integre a todos - pues la homogenización no se realiza de forma total" (Fajardo, 2005, p. 188).

Es así como, hoy por hoy, es difícil hablar de identidades impermeables, puesto que el acercamiento e intercambio de bienes y servicios entre ciudadanos de distintos territorios, a su vez globales, en un espacio y tiempo inmediato y fugaz, nos permite traer el término de "hibridación" citado por el autor García Canclini (1995), término que nos acerca a la significación de las identidades que se gestan en la actualidad. Teniendo en cuenta a Ortiz (1995) podemos visualizar algunas incidencias de la globalización en la constitución de identidad: desarraigo económico y cultural que distancia a las clases sociales más pobres del acceso al mercado del trabajo y del consumo, diversidad de culturas que incursionan en las distintas esferas sociales desvaneciendo las raíces nacionales y preparando el espacio para la pluralización de identidades; diglosia social, interrelaciones culturales en un mundo en donde es menos partícipe el arraigo y la identidad cultural y más atractivo la reinvención de nuevos modelos de vida, de ser y estar; de compenetrarse o de transformarse en la postmodernidad. Globalización, mundialidad, planetarización, entre otros términos; nos llevan a visualizar y reflexionar sobre las nuevas formas de interacción que el individuo va adoptando. No es una cuestión de opción sino de adaptación ante las cambiantes atmósferas de vivir la sociedad. En consecuencia, se desdibuja los referentes de lo local. La ciudad y los ciudadanos empiezan a matizarse proyectando nuevos rumbos y discursos político-culturales ${ }^{2}$. El autor Fajardo (2005) nos comparte la siguiente reflexión en cuanto a lo que vivimos hoy dentro de esta mundialización:

2 Surge una especie de subordinación de lo local; proceso disimulado por una adopción, fingidamente libre, de lo que circula como ideas, conocimiento; el imaginario social y los referentes político-culturales dominantes se imponen como "universales", a su vez que se particularizan dentro de lo local (Yory, 2006). Puesto que, la realidad cultural que circula ya no es referente de una identidad sólida y honesta. 
Cada lugar es descentrado por nuevos imaginarios y sensibilidades, impulsándose una deslocalización geocultural... la desterritorialización va proyectando una cierta "identidad de coproducción internacional" aún con sus diferencias y sus semejanzas...esto ha favorecido el surgimiento de una "territorialidad desarraigada" que construye "ciudades globales - collage", "memoria internacional popular", dando a entender que el desarraigo, la no raíz cultural, es la expresión de nuestra época (p. 191).

Así, se va configurando las nuevas formas de constituir la esencia del individuo, en donde la identidad se transmuta incesantemente; es variable, se adapta, se transforma, es efímera. Y es que, como bien lo dice Lipovetsky (2010), la cultura se ha transformado, es una cultura-mundo en la que la tecnología, el capitalismo, el consumismo, las industrias culturales, los medios y el internet reorganizan el mundo y a quienes viven en él. Hoy por hoy vivimos en un "Mundo que se vuelve cultura, cultura que se vuelve mundo: una culturamundo" (Lipovetsky, 2010, p. 9). Así, la cultura-mundo da cuenta de la problemática global a nivel de las crisis económicas, la violencia, la identidad, las crisis de sentido de la familia, de la vida misma, y en esta cultura-mundo está la risa, el humor, la distensión presente en la mediatización como parte de la saturación de imágenes, de mensajes que se apoyan en la multiplicación de escenas, que en programas como las Sitcoms crean espacios de relajamiento que van introduciendo e imponiendo nuevas lógicas acerca de la vida en torno al espectáculo, hasta que la vida misma se convierte en la espectacularización de las formas de vestir, hablar, ser, transformándose la realidad social en sí misma en un espectáculo, en el que el humor se ha convertido en una estratagema del mercado que los medios utilizan para colonizar la cultura y los modos de vida.

Entonces, las Sitcoms, se convierten en la parodia de la felicidad, para ello se valen de la globalización y la consecuente desterritorialización haciendo que las culturas, las costumbres y las ideologías ajenas se unifiquen y confluyan en torno a los medios en una especie de acercamiento que no unifica sino que promueve la pluralización, la hetoregenización y el desarraigo, pues "Uniformación globalitaria y fragmentación cultural van de la mano" (Lipovetsky, 2010, p. 19) ejemplo de ello es que, a pesar de que las costumbres nacionales parecieran hacerse borrosas ante el influjo de mensajes, imágenes, publicidad y marcas que fluyen desde diferentes lugares del planeta, sigue latente el afán de unos pocos por aferrarse a lo propio, observándose claramente que lo global se mantiene gracias a la relación dinámica con lo particular, con lo individual. 


\section{Conclusiones}

Nos encontramos en tiempos en los que los medios de comunicación pone en marcha todo el andamiaje de la globalización, estar aquí y allá sin barreras geográficas, ya que "la cultura se ha convertido en un mundo que tiene la circunferencia en todas partes y el centro en ninguna" (Lipovetsky, 2010, p. 8). Hay caos intelectual, confusión y desorientación. Sometidos a una nueva era, los ciudadanos ya no se reconocen culturalmente desde la antropología o desde la historia, desde ese acervo cultural tangible como las obras de arte o intangible como los ritos; los ciudadanos se reconocen en la medida que interactúan sobre una sociedad del mercado y del consumo. Vivimos en una sociedad del divertimento imbuida en una cultura-mundo en la que el humor hace parte de las experiencias consumistas. Así, las Sitcoms, se constituyen en la parodia de la felicidad, desterritorializan las culturas, las costumbres y las ideologías en favor de la pluralización, la hetoregenización y el desarraigo, pues "Uniformación globalitaria y fragmentación cultural van de la mano" (Lipovestky, 2010, p. 19).

Teniendo en cuenta que es prácticamente imposible escapar a los fenómenos de desterritorialización y transnacionalidad en la globalización, es importante que se creen espacios de posibilidad en los que los individuos puedan acercarse a la comprensión de lo que ocurre con la cultura en la televisión, ya que entender el rol de los medios, del consumo y del humor en la crítica social y la comercialización puede contribuir a que los ciudadanos desarrollen una postura crítica ante cómo se dan las dinámicas entre lo público y lo privado, es decir, entre lo local y lo global. Que quede como reflexión las palabras de García Canclini:

En las artes plásticas, en la música y en cualquier creación cultural siempre necesitamos oscilar entre la integración y el desenchufe. Es indispensable tener información internacional, no sólo para estar actualizados tecnológicay estéticamente sino también para nutrir la elaboración simbólica en la multiculturalidad de las migraciones, los intercambios y los cruces. Pero además hay momentos en que necesitamos replegarnos en lo propio, sea la peculiaridad nacional o étnica, las interacciones personales en los espacios domésticos o la modesta búsqueda individual (1995, p. 188). 


\section{Referencias bibliográficas}

Badillo, P.E. (2002). El Teatro Griego. Estudios sobre la tragedia, la comedia y la estructura gramática de las obras. Universidad de Puerto rico: puerto Rico.

Bajtín, M. (1991). Carnaval y literatura. Revista ECO, (129), 311-338.

Bergson, H. (2003). La risa. Ensayo sobre la significación de lo cómico. Argentina: Losada S.A.

Bonaut, J., \& Grandío, M. (2009). Los nuevos horizontes de la comedia televisiva en el siglo XXI. Revista Latina de Comunicación Social, (64), 753-765. La Laguna (Tenerife): Universidad de La Laguna. Recuperado de http://www.revistala tinacs.org/09/art/859_USJ/60_87_ Bonaut_y_Grandio.html

Coulet, C. (1999). El teatro griego. (F. Borrajo, trad.). España: Acento.

Grandío, M. (2009). El entretenimiento televisivo. Un estudio de audiencia desde la noción de gusto. Comunicación y Sociedad, 22(2), 139-158.

Fajardo, C. (2005). Estéticas y sensibilidades posmodernas. Estudio de sus nuevos contextos y categorías. México: instituto tecnológico y de estudios superiores de occidente (ITESO), Universidad Iberoamericana de León.

García Canclini, N. (1995). Consumidores y ciudadanos. México: Grijalbo.

Jamenson, F. (1998). El giro cultural. Escritos seleccionados sobre el postmodernismo 19831998. Buenos Aires: Manantial.

Jodelet, D. (2008). El movimiento de retorno al sujeto y el enfoque de las representaciones sociales. Cultura y representaciones sociales, 3(5), 32-63. Recuperado de http://www.culturayrs. org.mx/revista/num5/Jodelet.pdf.

Lindón, A. (23 de febrero de 2007). Diálogo con Néstor García Canclini. ¿Qué son los imaginarios y cómo actúan en la ciudad? Revista eure, 33(99), 89-99.

Lipovetsky, G. (1983). La era del vacío. Ensayos sobre el individualismo contemporáneo. (J. Vinyoli y M. Pendax, trads.). Barcelona: Anagrama, 2000.

Lipovetsky, G. (2010). La cultura-mundo. Barcelona: Anagrama.

López, N. (2008). Manual de guionista de comedias televisivas. Madrid: T\&B

Martín-Barbero, J., y Rey, G. (1999). Los ejercicios del ver. Hegemonía audiovisual y ficción televisiva. Barcelona: Editorial Gedisa. 
Martín-Barbero, J. (2012). Yo no fui a buscar los efectos, sino los reconocimientos. En J. Bonilla (Ed.). De las audiencias contemplativas a los productores conectados (pp. 19-38). Cali, Valle del Cauca: Sello Editorial javeriano.

Orozco, G. (2001). Televisión, audiencias y educación. Buenos Aires: Norma.

Orozco, G. (2012). Televisión y producción de interacciones comunicativas. Comunicación y sociedad. Nueva época, (18), 39-54. México: Universidad de Guadalajara.

Ortiz, R. (1995). Cultura, modernidad e identidades. Nueva Sociedad, (137), 17-23.

Ortiz, R. (1999). Cultura mundializada, modernidad y postmodernidad. Recuperado de http:// www.jstor.org/stable/41491590.

Pérez, C. J. (2009). La comedia colombiana: del éxito al olvido (tesis de pregrado). Bogotá: Universidad Javeriana.

Rincón, 0. (2006). Narrativas mediáticas o cómo se cuenta la sociedad del entretenimiento. España: Gedisa, S.A.

Yory, C. (2006). Ciudad, consumo y Globalización. Bogotá: Pontificia Universidad Javeriana. 